\title{
Profitability and productivity of potato (Solanum tuberosum) in Baglung district, Nepal
}

\author{
Mahima Bajracharya ${ }^{1}$ and Mahesh Sapkota ${ }^{2^{*}}$ (])
}

\begin{abstract}
Background: Potato is considered as staple food in Hill regions of Nepal. It is considered as a major crop (in cropping pattern) of the majority of the households in Bobang and Tara VDC of Baglung district. The potato produced in these VDCs has good market reputation and is the major source of income. There are very few research studies which have assessed the profitability of potato of these areas. So, this study was aimed to assess the profitability and productivity of potato in Baglung district of Nepal.
\end{abstract}

Methods: Potato is the fourth most important crop after major cereals. The two VDCs (Bobang and Tara) under Baglung district were purposively selected. These VDCs are good in potato production as compared to others in the district. The pretested semi-structured questionnaire was used to collect primary data. Households were selected using simple random sampling techniques. The respondents were interviewed using face-face interview method in the month of April 2016. Altogether, 120 samples (60 from each VDC) were selected and the data were coded and entered in SPSS software. The necessary result was obtained by analyzing socioeconomic and demographic characteristics, benefit-cost ratio and production function using SPSS, Stata and Microsoft excel.

Results: The average productivity was found 9.89 ton per hectare (ha) in the study area. The low productivity was due to disease infestation on crop. The per ha total cost of potato production was NRs. 197,186 with the total income of NRs. 268,047. The cost of FYM (45.32\%) was highest followed by seed and human labor. The per hectare profit from potato production was NRs. 70,861 with B/C ratio of 1.44 . An increase in $1 \%$ cost of human labor, seed and FYM would increase the total income of potato by $0.075,0.639$ and $0.190 \%$, whereas $1 \%$ increase in the cost of bullock labor and intercultural operation would decrease income by 0.015 and $0.047 \%$, respectively. The return to scale was found 0.842 which indicates decreasing return to the scale.

Conclusion: The per ha total income from potato was found NRs. 268,047 with B/C ratio of 1.44 in the study area. The low production and productivity was due to infestation of disease on standing crop. Technical and managerial skills on cultivation practices and provision of technical knowledge to control diseases as well as proper allocation of inputs and available resources would help to increase profitability and productivity of potato. It is suggested to use diseaseresistant improved varieties and follow appropriate recommended cultural practices.

Keywords: Benefit-cost ratio, Income, Potato, Production function

\section{Background}

Potato (Solanum tuberosum L.) is considered as one of the fourth most important crops in the world after wheat, rice and maize. It is one of the important cash crops to

\footnotetext{
*Correspondence: sapkotamahes@gmail.com

${ }^{2}$ Nepal Agricultural Research Council, Communication, Publication and Documentation Division, Pilot Program for Climate Resilience, Khumaltar, Lalitpur, Nepal

Full list of author information is available at the end of the article
}

address food insecurity and reduce poverty among smallholder farmers in the developing countries like Nepal [22, 23]. Its cultivation is popular among farmers due to its wider adaptability, high yield potential and high demand which contributes about 6.57 and $2.17 \%$ in AGDP and GDP, respectively. Potato is cultivated as a subsistence crop which is the best potential for yield increment and consists of high starch $(16.1 / 100 \mathrm{~g})$, protein $(2.1 / 100 \mathrm{~g})$, vitamin C (17.1 mg/100 g), potassium $(443 \mathrm{mg} / 100 \mathrm{~g})$ 
and essential amino acids [6]. Therefore, potatoes can be a good option to improve health and nutrition factor of rural population and is considered more productive than major cereals and has high economic value than cereals [10]. Potatoes are widely cultivated from the southern Terai at an altitude of $100 \mathrm{~m}$ mean above sea level (masl) to the northern mountains as high as $4000 \mathrm{~m}$ masl in Nepal (Web, May 18, 2016). It is grown in 197,037 hectares (ha) with $13.13 \mathrm{mt} /$ ha productivity and 2,586,287 $\mathrm{mt}$ production in Nepal [1]. In Baglung district, it is cultivated in 1665 ha, productivity of 11.8 ton/ha with the total production of 19,758 mt [4]. Potatoes are used as subsidiary food as part of vegetables in Terai region, whereas as staple food in Hill and Mountain regions. The demand of potato in the form of chips, fries and mashed potatoes has widened its scope which helps to uplift the economic condition of smallholder farmers. The majority of the farmers are smallholder having average of 0.68 ha of land size which requires commercialization for the better economic growth and development of least developed countries which rely on agriculture [17, 21,24]. The economy of people of Bobang and Tara VDC is dependent upon agriculture and mainly on potato farming [4]. Unavailability of quality seeds, lack of fertilizers at right time, shortage of labor, poor market, lack of technical knowledge on pest management and topographical barriers are the major problems observed in potato cultivation. The low volume of production and low price are major limitations in smallholder farmers to participate in competitive markets, and problem of fragmentation of land has hindered in commercialization. Potato has the potential to increase productivity by the use of scientific technology which helps in assuring food security [14]. There is no such remarkable improvement in agriculture sector despite of various plans, policies and programs made in periodic plans [19]. Some initiatives are in place to promote commercialization and intensification of potato in the study area. Thus, this study will be helpful in understanding the existing scenario of the potato growers, the methods and inputs they use for potato production, productivity and profitability of potato production in the study area.

\section{Research methodology}

Baglung district is one of the potential areas for potato cultivation. Geographically, it is located at $28^{\circ} 16^{\prime} \mathrm{N}$ and $83^{\circ} 36^{\prime} \mathrm{E}$ of Province No. 4. Potato was one of the major crops in cropping pattern of Bobang and Tara VDCs of Baglung district. The potato production is also high in these VDCs and has got good market reputation. So, these VDCs were selected purposively for this study (Table 1). The study site is indicated in Fig. 1 . The total of 120 samples (sixty from each VDC) was selected

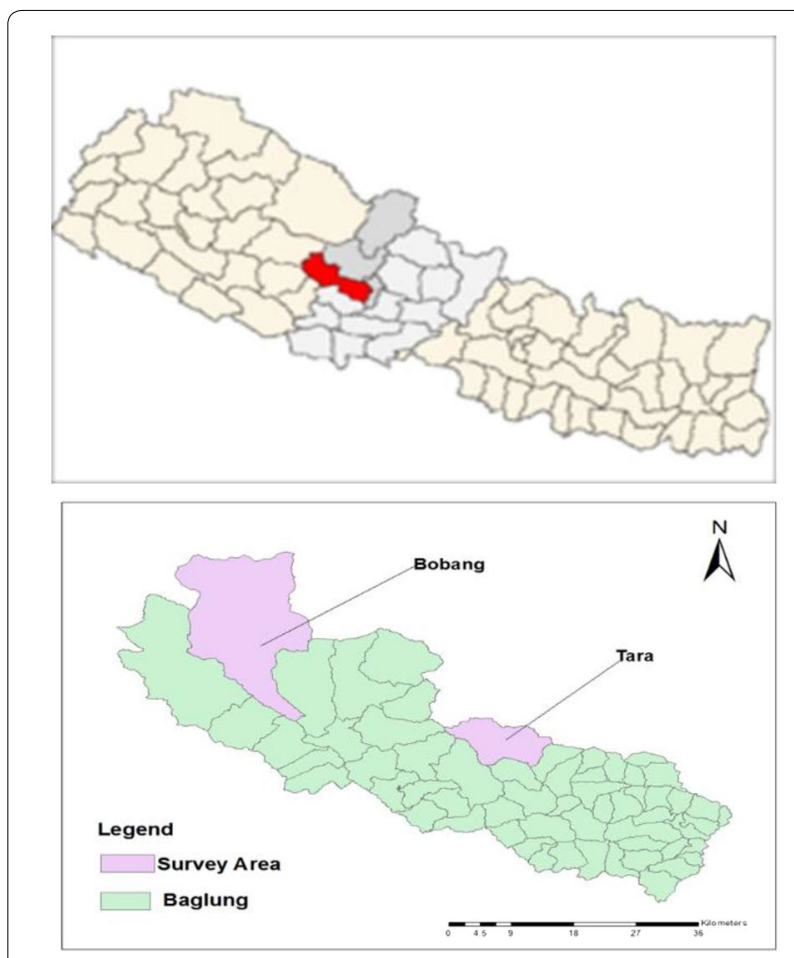

Fig. 1 Map of Nepal and Baglung district indicating study area. Red shaded area indicate Baglung district

using simple random sampling technique. Face-face interview method was used to collect primary data using pretested semi-structured questionnaire in the month of April 2016. Data about socioeconomic and demographic information, variable cost incurred in production as well as income from potato were collected during survey. Altogether, two Focus Group Discussion (FGD), each on one VDC, and key informant interview were conducted to validate information obtained from respondents. Secondary data were collected from various published articles, government publications, various books, Web sites, etc. Collected data were coded and entered in Statistical Package for Social Sciences (SPSS), and the necessary inference was derived using Microsoft Excel, SPSS and Stata software.

\section{Gross margin analysis}

Gross margin was calculated as:

Gross margin $=$ Gross return - Total variable cost

where Gross return $=$ Price of potato $\times$ Total potato production.

Total variable cost $=$ Summation of all variable costs

Variable costs $=$ Cost of seed, FYM, human labor, bullock labor, intercultural operation and other cost 
Table 1 Characteristics of VDCs Source [4] and author's illustration

\begin{tabular}{lll}
\hline Characteristics & Bobang & Tara \\
\hline Altitude & $2000-2650 \mathrm{~m}$ & $2000-2400 \mathrm{~m}$ \\
Major ethnic groups & Dalits and Magars & Magars, Brahmins and Dalits \\
Planting time & Falgun - Chaitra & Late Magh - Falgun \\
Harvesting time & Ashad - Bhadra & Ashad - Bhadra \\
Distance from district headquarter & $116 \mathrm{~km}$ (pakki + kachi baato) & $68 \mathrm{~km}$ (pakki + kachibaato) \\
Access to extension services & Very poor & Relatively better \\
\hline
\end{tabular}

(Other cost includes transportation cost from field to storage area and cost for loading and unloading during marketing).

\section{Benefit-cost analysis}

Benefit-cost analysis was carried out by using the formula:

$$
B / C \text { ratio }=\frac{\text { Gross Return }}{\text { Total variable cost }}
$$

\section{Production function analysis}

Cobb-Douglas production function (CDPF) is the most common and widely used [7, 13, 18, 23] technique in the field of economics to represent the technological relationship between the various inputs used and output produced. The coefficients represent the elasticity of respective inputs, and its summation provides the value of return to scale. The following form of CDPF was used:

$$
Y=a X_{1}^{b_{1}} X_{2}^{b_{2}} X_{3}^{b_{3}} X_{4}^{b_{4}} X_{5}^{b_{5}} e^{u}
$$

where $Y$ is the total income from potato production in hectare (NRs.), $X_{1}$ cost of human labor (NRs.), $X_{2}$ cost of bullock labor (NRs.), $X_{3}$ expenditure on seed (NRs.), $X_{4}$ expenditure on farmyard manure (NRs.), $X_{5}$ cost of intercultural operations (NRs.), $e$ error term and $b_{1} \ldots \mathrm{b}_{5}$ coefficients to be estimated.

The CDPF in the form expressed above was linearized in a logarithmic function for the ease in computation.

$$
\begin{aligned}
\ln Y= & \ln a+b_{1} \ln X_{1}+b_{2} \ln X_{2}+b_{3} \ln X_{3} \\
& +b_{4} \ln X_{4}+b_{5} \ln X_{5}+u
\end{aligned}
$$

where $\ln =$ natural logarithm, $a=$ constant and $u=$ random disturbance term.

\section{Return to scale analysis}

Return to scale describes the response of an output toward its overall proportional change from input. The summation of respective coefficients obtained from CDPF gives the value of return to scale.

Return to scale (RTS) = Summation of coefficients

$$
\left(b_{1}+b_{2}+\cdots+b_{5}\right)
$$

Decision rule:

RTS > 1: Increasing return to scale

RTS $=1$ : Constant return to scale

RTS $<1$ : Decreasing return to scale.

\section{Results and discussion \\ Description of socioeconomic and demographic characteristics}

The majority of the households (85.8\%) had agriculture as their major occupation. The average age of the household head was found 47.91 years which ranged from 22 to 82 years. The average age of the household head in Bobang VDC was 49.08 years as compared to Tara VDC of 46.73 years, respectively, and the differences, however, were statistically nonsignificant (Table 2). About 90\% households were male headed in the study area. It was observed, the higher percentage of male-headed household $(91.7 \%)$ in Bobang as compared to Tara VDC (88.3\%). The majority $(51.7 \%)$ of the households were Janajati (especially Magar) in which the higher percentage of Dalit (55\%) was observed in Bobang in comparison with Tara VDC (Janajati = 58\%). The difference was statistically significant at $1 \%$ level. The average household size was found six members with a minimum of two members and maximum of 13 members in household. The average household size was almost similar for both VDCs as well. The average educated members in the household were five and the same was true for VDCs under this study. Further, the average schooling year of the household head was 3 years which ranged from zero to 12 years. The average years of schooling of the household head were 2.45 years in Bobang and 3.67 years in Tara where the difference was statistically significant at $5 \%$ level. Economically active members are those who belong to the age group of 15-60 years, whereas dependency ratio is the ratio of dependent members (age group of below 15 years and above 60 years of age) to the economically active members [3]. There were 3.55 and 3.70 economically active members in Bobang and Tara VDC and dependency ratio was 0.86 and 0.89 , respectively. The 
Table 2 Socioeconomic and demographic characteristics

\begin{tabular}{|c|c|c|c|c|c|}
\hline \multirow[t]{2}{*}{ Variables } & \multirow[t]{2}{*}{ Total $(n=120)$} & \multicolumn{2}{|l|}{ VDC } & \multirow[t]{2}{*}{ Mean difference } & \multirow[t]{2}{*}{$t$ value } \\
\hline & & Bobang $(n=60)$ & Tara $(n=60)$ & & \\
\hline Age of respondent (year) & $42.05(12.67)$ & $42.87(14.36)$ & $41.23(10.78)$ & 1.633 & 0.705 \\
\hline Age of household head (year) & $47.91(13.27)$ & $49.08(13.93)$ & $46.73(12.58)$ & 2.350 & 0.970 \\
\hline Schooling of household head (year) & $3.06(3.33)$ & $2.45(2.97)$ & $3.67(3.59)$ & $-1.216^{* *}$ & -2.023 \\
\hline Household size & $6.20(2.41)$ & $6.12(2.44)$ & $6.28(2.39)$ & -0.167 & -0.378 \\
\hline Male members in $\mathrm{HH}$ & $3.26(1.53)$ & $3.07(1.41)$ & $3.45(1.62)$ & -0.383 & -1.381 \\
\hline Female members in $\mathrm{HH}$ & $2.94(1.44)$ & $3.05(1.52)$ & $2.83(1.36)$ & 0.217 & 0.823 \\
\hline Economically active members & $3.63(1.81)$ & $3.55(1.83)$ & $3.70(1.80)$ & -0.150 & -0.453 \\
\hline Dependency ratio & $0.88(0.71)$ & $0.86(0.66)$ & $0.89(0.77)$ & -0.023 & -0.176 \\
\hline Educated members in household & $4.81(2.42)$ & $4.50(2.57)$ & $5.12(2.23)$ & -0.617 & -1.404 \\
\hline Total landholding (ha) & $0.89(0.83)$ & $0.53(0.50)$ & $1.23(0.93)$ & $-0.723^{* * *}$ & -5.316 \\
\hline Cultivable land (ha) & $0.36(0.29)$ & $0.26(0.26)$ & $0.45(0.29)$ & $-0.190^{* *}$ & -3.804 \\
\hline Land area under potato cultivation (ha) & $0.19(0.13)$ & $0.19(0.13)$ & $0.17(0.13)$ & $-0.047^{* * *}$ & -2.026 \\
\hline Livestock holding (LSU) & $5.61(5.77)$ & $6.38(7.21)$ & $4.84(3.73)$ & 1.548 & 1.477 \\
\hline
\end{tabular}

Values in parentheses indicate SD

***,** Significant at 1 and $5 \%$ levels, respectively

differences were statistically nonsignificant. The average landholding was 0.89 hectare (ha) which was higher than the national average on landholding (0.68 ha). The average landholding was low (0.53 ha) in Bobang in comparison with Tara (1.23 ha), and the difference was statistically significant at $1 \%$ level. Similarly, the average landholding under potato cultivation was 0.19 ha. The average area under potato cultivation was significantly higher (0.19 ha) in Bobang as compared to Tara (0.17 ha) which was statistically significant at $1 \%$ level. The average livestock holding was found $5.61 \mathrm{LSU}^{1}$ in the study area with higher (6.38) LSU in Bobang as compared to Tara (4.84).

\section{Cropping pattern}

Cropping pattern refers to the sequence of crops grown in the same piece of land in a year. It gives clear idea about the different kinds of crop grown in that locality. Generally, cropping pattern of the locality is influenced by climatic condition, geographical situation, socioeconomic characteristics, physical infrastructures and feeding habit of the locality [25].

Cropping pattern in the study areas

\begin{tabular}{ll}
\hline Bobang VDC & Tara VDC \\
\hline Potato - fallow & Potato - maize \\
Potato - barley & Potato + Bhago - maize
\end{tabular}

\footnotetext{
${ }^{1}$ Livestock standard unit (LSU) $=1$ cow/bull +1.5 buffalo +0.6 swine $/$ pig +0.4 goat/sheep +0.02 poultry [8] cited from Ghimire 2012 and Dhakal [5].
}

\begin{tabular}{ll}
\hline Bobang VDC & Tara VDC \\
\hline Potato - beans & Potato - barley \\
$\begin{array}{c}\text { Potato - vegetables (cauliflower, } \\
\text { cabbage, tomato, hot pepper) }\end{array}$ & Potato - fallow \\
\hline
\end{tabular}

\section{Inputs used and cost of potato production}

The major inputs used in the production of potato were seed, human labor, bullock labor and farmyard manure (FYM). The human labor (both male and female) was used mainly for land preparation, sowing potato tubers, weeding and harvesting. Males were involved more in land preparation and females in sowing, weeding and harvesting.

The average amount of seed required was found $1391 \mathrm{~kg}$ per hectare which was lower than the recommended rate by the Government of Nepal, Department of Agriculture (1500-2000 kg/ha). The higher seed rate was observed in Bobang VDC (1484 kg/ha) as compared to Tara VDC (1298 kg/ha), and the difference was statistically significant at $1 \%$ level (Table 3 ). The reason behind the difference in the seed rate between two VDCs was size of seed tubers used. In Bobang, bigger seed tubers were used as planting material as compared to Tara. They were not aware of the size of potato to be used for seed purpose. Likewise, the average human labor employed in potato production was higher (93 mandays/ ha) in Bobang as compared to Tara VDC (87 mandays/ ha); however, the difference was statistically nonsignificant. The use of bullock labor for land preparation and the time spent in intercultural operations (in hours) were also found higher in Bobang in comparison with 
Table 3 Inputs used for potato production

\begin{tabular}{|c|c|c|c|c|c|}
\hline \multirow[t]{2}{*}{ Inputs } & \multirow[t]{2}{*}{ Total } & \multicolumn{2}{|l|}{ VDC } & \multirow[t]{2}{*}{ Mean difference } & \multirow[t]{2}{*}{$t$ value } \\
\hline & & Bobang & Tara & & \\
\hline Seed (kg/ha) & $1391.08(317.75)$ & $1484(348.84)$ & $1298.17(253.75)$ & $185.83^{* * *}$ & 3.337 \\
\hline Human labor (mandays/ha) & $89.90(39.94)$ & $92.76(37.53)$ & $87.04(42.35)$ & 5.73 & 0.784 \\
\hline Bullock labor (days/ha) & $8.08(4.32)$ & $9.87(5.17)$ & $7.73(2.92)$ & $2.14^{* * *}$ & 2.793 \\
\hline FYM (doko/ha) & $1862.68(1234.24)$ & $1410.21(759.69)$ & $2315.15(1441.88)$ & $-904.93^{* * *}$ & -4.301 \\
\hline Intercultural operation (h/ha) & $203.83(73.83)$ & $219.47(57.89)$ & $188.18(84.52)$ & $31.29^{* *}$ & 2.366 \\
\hline
\end{tabular}

Values in parentheses indicate SD

***,** Significant at 1 and 5\% levels, respectively

Table 4 Cost of potato cultivation (NRs./ha)

\begin{tabular}{|c|c|c|c|c|c|}
\hline \multirow[t]{2}{*}{ Cost items } & \multirow[t]{2}{*}{ Total } & \multicolumn{2}{|l|}{ VDC } & \multirow[t]{2}{*}{ Mean difference } & \multirow[t]{2}{*}{$t$ value } \\
\hline & & Bobang & Tara & & \\
\hline Seed cost & $46,771(11,049)$ & $49,684(11,828)$ & $43,859(9437)$ & $5825.11^{* * *}$ & 2.982 \\
\hline Human labor cost & $40,455(17,975)$ & $41,743(16,887)$ & $39,166(19,055)$ & 2577.32 & 0.784 \\
\hline Bullock labor cost & 4607 (2258) & $5142(2695)$ & $4073(1561)$ & $1069.23^{* * *}$ & 2.659 \\
\hline FYM cost & $89,372(69,621$ & $56,046(30,589)$ & $122,697(81,127)$ & $-66,651.26^{* * *}$ & -5.955 \\
\hline Intercultural operation cost & $10,124(37,923)$ & $11,353(3458)$ & $8896(37,389)$ & $2458^{* * *}$ & 3.738 \\
\hline Others cost & 5857 (6559) & $6756(8869)$ & $4957(2452)$ & 1800 & 1.511 \\
\hline Total cost & $197,186(76,225)$ & $170,725(43,531)$ & $223,647(91,651)$ & $-52,922^{* * *}$ & -4.040 \\
\hline
\end{tabular}

Values in parentheses indicate SD

***,** Significant at 1 and 5\% levels, respectively

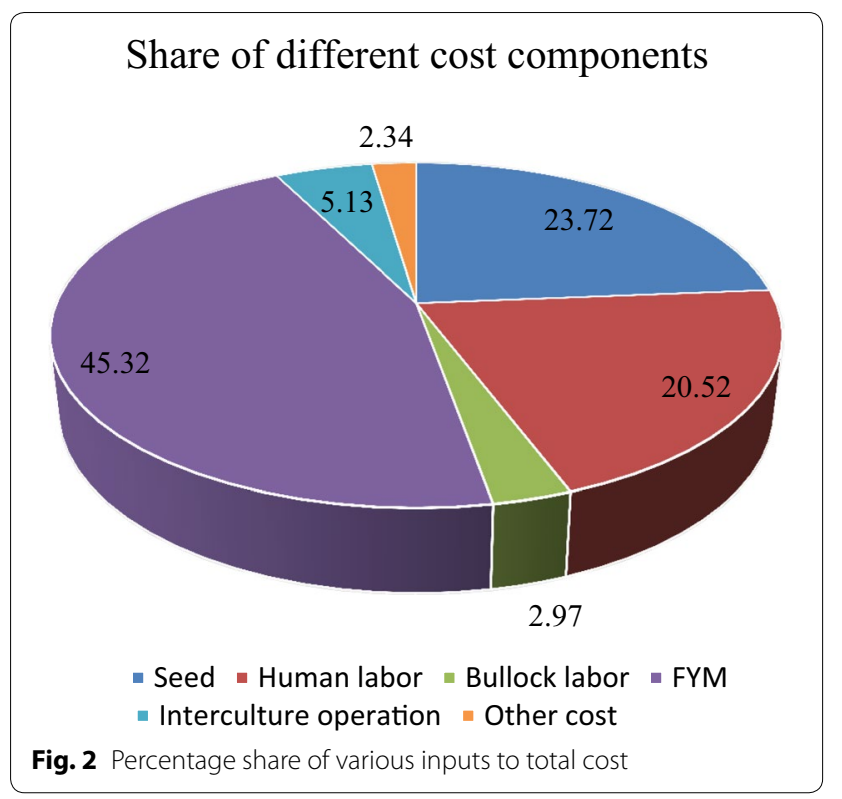

Tara VDC. The difference was found statistically significant at 1 and $5 \%$ level, respectively. The use of FYM was significantly low in Bobang (1410 doko/ha) as compared to Tara (2315 $\left.d o k o^{2} / \mathrm{ha}\right)$, and this difference was statistically significant at $1 \%$ level.

The average total cost incurred in potato production was found NRs. 197,186 per hectare (Table 4). The total cost of production per hectare in Bobang was significantly low (NRs. 170,725) as compared to Tara VDC (NRs. 223,647), and the difference across VDC was statistically significant at $1 \%$ level. The total cost of FYM used was maximum (45.32\%) which indicated the major input used for potato production (Fig. 2) followed by seed $(23.72 \%)$ and human labor (20.52\%) in the study area, and this finding was in line with [16]. They had reported that the share of the cost of FYM was highest among others in maize production in Chitwan district. Sapkota et al. [20] also reported high cost of FYM in maize seed production in Palpa district. The higher cost of cultivation in Tara VDC was due to high cost of FYM used as compared to Bobang. It was interesting to note that there was no use of chemical fertilizer and any sort of chemical pesticides in the study area. During FGD and KII, it was found that

\footnotetext{
${ }^{2}$ One doko FYM $=40 \mathrm{~kg}$ (source: FGDs, Key Informant Interview with DADO).
} 
Table 5 Production, productivity and profitability of potato production

\begin{tabular}{|c|c|c|c|c|c|}
\hline \multirow[t]{2}{*}{ Particulars } & \multirow[t]{2}{*}{ Total } & \multicolumn{2}{|l|}{ VDC } & \multirow[t]{2}{*}{ Mean difference } & \multirow[t]{2}{*}{$t$ value } \\
\hline & & Bobang & Tara & & \\
\hline Production in $\mathrm{HH}(\mathrm{kg})$ & $1765(1221)$ & $1484(975)$ & 2045 (1377) & $-561^{* *}$ & -2.577 \\
\hline Productivity (kg/ha) & $9890(4598)$ & 10,135 (4982) & 9645 (4208) & 489 & 0.582 \\
\hline Revenue & $268,047(136,142)$ & $258,878(143,859)$ & $277,215(128,520)$ & $-18,336.48$ & -0.736 \\
\hline Profit & $70,860(130,923)$ & $88,153(135,386)$ & $53,567(125,038)$ & $34,585.57$ & 1.454 \\
\hline
\end{tabular}

Values in parentheses indicate SD.

** Denotes significant at $5 \%$ level

people were aware of the negative impacts of the use of chemical fertilizer and pesticides in long term. So farmers were found not using such chemicals.

\section{Production, productivity and profitability of potato}

The average production of potato per household and productivity was $1765 \mathrm{~kg}$ and $9890 \mathrm{~kg} / \mathrm{ha}$ in the study area. The total production of potato per household was found low in Bobang (1484 kg) as compared to Tara VDC $(2045 \mathrm{~kg})$, and the difference was statistically significant at $5 \%$ level (Table 5). The higher production in Tara VDC was due to better cultivation practices like application of FYM, better quality of potato tubers and comparatively better technical support from agricultural service center, i.e., extension services. But, the productivity of potato was found higher in Bobang VDC (10.14 mt/ha) as compared to Tara VDC (9.65 mt/ha); however, the difference was statistically nonsignificant. The overall productivity $(9.89 \mathrm{mt} / \mathrm{ha})$ was less than the district and national average data. The reason for low productiivity was due to disease infestation on standing crop followed by unfavorable environment conditions which led to less production in the year 2016. Thus, it is recommended to use disease-resistant improved seed cultivars. It is suggested to use homeproduced seeds only after seed treatment to minimize the loss. There is need to increase extension services from technical experts who would help to bring changes in existing cultivation practices, introduce improved potato varieties and improve technical and managerial skills of farmers [11]. The average gross revenue from potato production was found NRs. 268,047 per hectare. The revenue from potato production was higher (NRs. 277,215) in Tara VDC as compared to Bobang (NRs. 258,878); however, the difference was statistically nonsignificant. The higher revenue in Tara VDC was due to high production, high price of potato, nearer to market access and having good market reputation. The cooking quality and taste of these potatoes had made them popular all over the district. The per hectare profit from potato production was NRs. 70,861 in the study area, higher in Bobang (NRs. 88,153) as compared to Tara VDC (NRs. 53,568). Sapkota et al.
[20] also revealed that the maize foundation seed production was profitable in Palpa district.

\section{Benefit-cost analysis}

The per $\mathrm{kg}$ cost of potato production was found NRs. 23.20 and the price was NRs. 26.71 which result the $B / C$ ratio of 1.44 in the study area (Table 6). This showed that one rupee spent on production yields 44 paisa of benefit from potato. The potato production was profitable in the study area. The $B / C$ ratio of Bobang was higher (1.53) as compared to Tara VDC (1.35). The $B / C$ ratio was very low as compared to the national computation made in 2014 in Baglung district which was 2.20 [15]. The reason for low $B / C$ ratio was an increase in costs of labor and FYM. There was high infestation of disease on potato in the year 2016 which led to low production and low benefit-cost ratio in the study area. Timsina et al. [22] in their study also found potato production as profitable crop with benefit-cost ratio 2.9 in Taplejung district of Nepal.

\section{Production function analysis}

The $F$ value (40.76) was statistically significant at $1 \%$ level which indicated that the model has good explanatory power. The value of $R^{2}$ indicated that about $63 \%$ variations in dependent variable were well explained by explanatory variables included in the model (Table 7).

Keeping all other factor constant, it is evident that $1 \%$ increase in the cost of human labor would increase the income from potato production by $0.075 \%$; however, the increment was found statistically nonsignificant. The result revealed that $1 \%$ increase in cost of bullock labor would decrease the income from potato production by

Table 6 Benefit-cost ratio of potato cultivation

\begin{tabular}{lclr}
\hline Particulars & Total & \multicolumn{2}{l}{ VDC } \\
\cline { 3 - 4 } & & Bobang & Tara \\
\hline Cost (NRs./kg) & 23.20 & 19.00 & 27.40 \\
Price (NRs./kg) & 26.71 & 25.24 & 28.19 \\
Benefit-cost ratio & 1.44 & 1.53 & 1.35 \\
\hline
\end{tabular}


Table 7 Production function analysis of potato production

\begin{tabular}{lclrl}
\hline Explanatory variables & Coefficient & Standard error & $\boldsymbol{t}$ value & $\boldsymbol{P}>|\boldsymbol{t}|$ \\
\hline Log_Human labor cost & 0.075 & 0.124 & 0.60 & 0.547 \\
Log_Bullock labor cost & -0.153 & 0.018 & -0.86 & 0.394 \\
Log_Seed cost & $0.639^{* * *}$ & 0.122 & 5.24 & 0.000 \\
Log_FYM cost & $0.190^{* * *}$ & 0.058 & 3.25 & 0.002 \\
Log_Intercultural opera- & -0.047 & 0.105 & -0.44 & 0.657 \\
$\quad$ tion cost & & & & \\
Constant & $2.878^{* * *}$ & 0.647 & 4.45 & 0.000 \\
$R^{2}$ & 0.641 & & & \\
Adjusted $R^{2}$ & 0.626 & & & \\
Fvalue & $40.76^{* * *}$ & & & \\
Returns to scale ( $\sum$ bi) & 0.842 & & & \\
*** Significant at 1\% level & & & &
\end{tabular}

0.015. There is an increase in days required for land preparation using bullock which increases the cost of production and reduces total income. Similarly, $1 \%$ increase in cost of seed would increase the total income by $0.639 \%$ which was significant at $1 \%$ level. The regression coefficient of FYM indicated that $1 \%$ increase in expenditure on FYM would increase the total income by $0.190 \%$ which was statistically significant at $1 \%$ level. Tolno et al. [23] revealed the positive impact of fertilizer on the production of potato in Guinea. Similar to this finding, Ghimire and Dhakal [9] found a significant impact of organic manure on the productivity of cauliflower. Similarly, Akter et al. [2] also found the significant effect on the income from tomato production. Finally, $1 \%$ increase in the expenditure on the intercultural operation would decrease the total income from potato production by $0.047 \%$ which was statistically nonsignificant. The finding was in line with Sapkota et al. [20] who found the positive increment in income when there is an increase in cost of seed, FYM and labor by $1 \%$ but decrease in income when there is an increase in cost of tillage in maize seed production. Tolno et al. [23] found the inputs such as seed, labor and fertilizer as over-utilized resources in the production of potato.

\section{Return to scale analysis}

The sum of regression coefficients obtained from CDPF was 0.842 which indicated the decreasing return to scale in potato production. This implies that an increase in the cost of variable inputs would return lesser amount of income from potato production. The additional proportion of output is smaller than the additional input employed. Sapkota et al. [20] also found return to scale as 0.861 in the study conducted in 2016 on maize seed production in Palpa district of Nepal. But, the result was in contrast to that of Mahatha [12] who estimated elasticity of production as more than unity (1.85) in potato production.

\section{Conclusion}

The study area was dominated by male society with the majority of Janajati (especially Magar). There were about four economically active members with an average of 0.88 dependency ratio. The area under potato cultivation was only 0.19 ha with significantly different area under potato in the VDCs. The average livestock holding was 5.61 LSU. The potato was the major and most important crop in the cropping pattern of the majority of the farmers. Farmers were unaware of the recommended rate of seed rate and had a practice of the use of low seed rate. The per hectare total cost of potato production was NRs. 197,186. The cost of FYM was highest (45.32\%) followed by seed (23.72\%) and human labor (20.52\%). The high cost of FYM led to low $B / C$ ratio. It was very interesting to note that farmers were found not using any sort of chemical fertilizer and pesticides in the field. They had a belief and are aware that use of such chemicals would decrease the soil fertility as well as increase the chances of disease infestation. The overall potato production per hectare was lower than the average production of district and the nation. The low productivity was mainly due to disease infestation. The per hectare total income from potato production was found NRs. 268,047 with $B / C$ ratio of 1.44 which indicates profitability. An increase in $1 \%$ cost of human labor, seed and FYM would increase the total income from potato by $0.075,0.639$ and $0.190 \%$, whereas an increase in $1 \%$ cost of bullock labor and intercultural operation would decrease the total income by 0.015 and $0.047 \%$, respectively. The return to scale was found 0.842 , indicating decreasing return to scale. This revealed that there is need of proper allocation and utilization of resources (inputs) to increase the income from potato production. The potato produced from these areas has good cooking quality and taste and has got good market reputation. There is need of dissemination of appropriate technical knowledge about the effective management of diseases so that the profitability could be increased. Farmers are suggested to adopt disease-resistant seed varieties and practice recommended cultural practices.

\section{Abbreviations \\ \%:: Percent; \&: And; B/C: Benefit-cost; AGDP: Agriculture Gross Domestic Product; CDPF: Cobb-Douglas production function; DADO: District Agriculture Development Office; FGD: Focus Group Discussion; GDP: Gross Domestic Product; h: Hour; Ha: Hectare; HH: Household; kg/ha: Kilogram per hectare; KIl: Key informant interview; m: Meter; masl: Mean above sea level; mt: Metric tonnes; NRs.: Nepali rupees; SPSS: Statistical Package for Social Sciences; VDC: Village Development Committee.}

\section{Authors' contributions}

$M B$ is the principal researcher, prepared interview schedule to collect data, analysis and prepared this manuscript. MS has guided MB while undertaking 
this research from the very beginning of the study. He helped MB in data entry, analysis, revised manuscript minutely with critical comments and suggestions and drafted the manuscript. Both authors read and approved the final manuscript.

\section{Author details}

${ }^{1}$ Ministry of Agricultural Development, District Agriculture Development Office, Baglung, Nepal. ${ }^{2}$ Nepal Agricultural Research Council, Communication, Publication and Documentation Division, Pilot Program for Climate Resilience, Khumaltar, Lalitpur, Nepal.

\section{Acknowledgements}

We are thankful to all those respondents of Baglung district who provided reliable data to complete this study. We would like to express our gratitude to Agriculture and Forestry University (AFU), Rampur, Chitwan, Nepal, for providing the favorable environment for this study. We appreciate our colleagues for their direct and indirect support to accomplish this research.

\section{Competing interests}

The authors declare that they have no competing interests.

\section{Availability of data and materials}

The datasets used and analyzed during the current study are available from the first author on reasonable request.

\section{Consent for publication}

A verbal consent for publication has been received from the participants of the interview schedule, FGD and KIl under the condition of anonymity, which was strictly maintained in this research paper.

\section{Funding}

This study was financially supported by National Agricultural Research and Development Fund (NARDF), Singha Durbar Plaza, Kathmandu, Nepal.

\section{Publisher's Note}

Springer Nature remains neutral with regard to jurisdictional claims in published maps and institutional affiliations.

Received: 18 April 2017 Accepted: 31 May 2017

Published online: 13 June 2017

\section{References}

1. AICC. Krishi Diary. Agriculture Information and Communication Centre. Ministry of Agricultural Development, Department of Agriculture, Hariharbhawan, Lalitpur; 2016

2. Adhikari 2000 cited in Ghimire B. Assessment of socio-economic impact of sustainable soil management practices on vegetables in Nalang and Salang VDCs of Dhading district (master's thesis). Master thesis submitted to Institute of Agriculture and Animal Science for the partial fulfillment of the requirements for the degree of Master of Science in Agriculture (AgriEconomics), Rampur, Chitwan, Tribhuvan University, Nepal (2012).

3. Akter S, Islam MS, Rahman MS. An economic analysis of winter vegetables production in some selected areas of Narsingdi district. J Bangladesh Agric Univ. 2012;9(2):241-6.

4. CBS. Population monograph of Nepal. Government of Nepal, National Planning Commission Secretariat, Central Bureau of Statistics, Ramshah Path, Kathmandu; 2014.

5. CIP. Potato facts. Processed. Lima: International Potato Center (CIP); 2010. p. 4
6. DADO Baglung. Annual agriculture development program and statistics book. Baglung: F.Y. 2071/72 Government of Nepal, Ministry of Agricultural Development, District Agriculture Development Office; 2015.

7. Dhakal S. Assessment of climate smart sustainable soil management practices and their impacts on farmer's livelihood in Khotang, Nepal. Master thesis submitted to Agriculture and Forestry University for the partial fulfillment of the requirements for the degree of Master of Science in Agriculture (Agricultural Economics), Rampur, Chitwan (2015).

8. FAO (2008). http://www.fao.org/potato-2008/en/potato/factsheets.html.

9. Fasasi AR. Resource use efficiency in yam production in Ondo State, Central Nigeria. Agric J. 2006:1:36-40.

10. Ghimire B, Dhakal SC. Production Economics of Sustainable Soil Management based Cauliflower (Brassicae oleracea. L. var. botrytis) in Dhading district of Nepal. American. J Agric For. 2014;2(4):199-205.

11. Kafle B, Shah P. Adoption of improved potato varieties in Nepal: a case of Bara District. J Agric Sci. 2012; 7(1).

12. MRSMP. Cost of production \& marketing margin of cereal, cash, vegetable \& spices crops in Nepal 2070/2071 (2013/2014). Market Research and Statistics Management Program. Hariharbhawan: Ministry of Agricultural Development; 2014.

13. Mahatha RK. Economics of production and marketing of Potato in Saptari district of Nepal (master's thesis). Institute of Agriculture and Animal Science, Tribhuvan University, Chitwan, Nepal (2012).

14. Manjunah K, Dhananjaya Swamy PS, Jamkhandi BR, Nadomi NN. Resource use efficiency of Bt cotton and non-Bt cotton in Haveri District of Karnataka. Int J Agric Food Sci Technol. 2013;4(3):253-8.

15. MoF. Economic survey fiscal year 2015/16. Government of Nepal, Ministry of Finance, Singha Durbar, Kathmandu; 2016.

16. Paudel P, Matsuoka A. Cost efficiency estimates of maize production in Nepal; A case study of Chitwan district. Agricu Econ. 2009;55(3):139-48.

17. Pingali LP, Rosegrant MW. Agricultural commercialization and diversification: process and polices. Food Policy. 1995;20(3):171-85.

18. Rahman SA, Lawal AB. Economic analysis of maize based cropping systems in Giwi local Government area of Kaduna state, Nigeria. Int J Agric Sci Environ Tech. 2003:3(2):139-48.

19. Sapkota M, Joshi NP, Kattel RR, Bajracharya M. Determinants of maize seed income and adoption of foundation seed production: evidence from Palpa District of Nepal. Agric. Food Secur. 2017. doi:10.1186/ s40066-017-0119-3

20. Sapkota M. Economic analysis of maize seed production in Palpa district of Nepal: Prospects of improving technical efficiency. A master thesis submitted to Agriculture and Forestry University in partial fulfillment of the requirements for the degree of Master of Science in Agriculture (Agricultural Economics), Rampur, Chitwan (2016).

21. Timmer CP. Farmers and markets: the political economy of new paradigms. Am J Agr Econ. 1997;79(2):621-7.

22. Timsina KP, Kafle K, Sapkota S. Economics of potato (Solanum tuberosum L.) production in Taplejung district of Nepal. Agron J Nepal. $2013 \cdot 2 \cdot 173-81$

23. Tolno E, Kobayashi H, Ichizen M, Esham M, Balde BS. Potato production and supply by smallholder farmers in Guinea: an economic analysis. Asian J Agric Ext Econ Soc. 2016;8(3):1-16

24. Von Braun J, Kennedy E. Agricultural commercialization, economic development and nutrition. Baltimore: Johns Hopkins University Press for International Food Policy Research Institute; 1994.

25. Yadav S, Srivastava A, Bag T, Kumar Y, Kumar S. Productivity, profitability and resource use efficiency of potato (Solanum tuberosum) based cropping systems in eastern Himalayan region. Indian J Agric Sci. 2015:85(7):921-5.

26. "In Nepal, potato is widely cultivated from the southern Terai". (2016, May 16). http://www.potatopro.com/nepal/potato-statistics. 